\title{
Analisis Kondisi Ekonomi Global Terhadap Pergerakan IDX30 Selama Pandemi Covid 19
}

\author{
Siti Wardani Bakri Katti \\ Program Studi Manajemen, Institut Bisnis dan Keuangan Nitro Makassar \\ ${ }^{1}$ E-mail: siti.wardani88@gmail.com
}

\begin{abstract}
This study aimed to determine the effect of global economic uncertainty which comprises: world oil price, Federal fund rate, Dow Jones Industrial Average Index and the Rupiah currency partially or simultaneously on the capital market. In this study IDX30 index used as research objects that represent the capital market, as well as to determine the dominant variable affecting IDX30 index. The population in this study all companies included in the IDX30 index members. Samples were taken using saturation sampling, that the whole company is a member IDX30 index used as a sample. Data analysis techniques used in this research is multiple linear regression analysis. The result showed: (1) World oil price do not significantly influence the IDX30 index, (2) Federal fund rate significantly influence IDX30 index, (3) Rupiah currency significant effect on IDX30, (4) Dow Jones Industrial Average index significantly influence IDX30 index, (5) World oil price, Federal fund rate, Dow Jones Industrial Average index and Rupiah currency simultaneously significant effect on the IDX30 index, as well as, (6) the dominant variable affecting IDX30 index is the Dow Jones Industrial Average index.
\end{abstract}

Keywords: IDX30 Index, World Oil Price, Federal Fund Rate, Rupiah Currency, Dow Jones Index.

\section{PENDAHULUAN}

Kondisi ekonomi global merupakan salah satu indikator ekonomi makro yang dapat memengaruhi pergerakan indeks harga saham di Bursa Efek Indonesia. Kondisi perekonomian global saat ini tengah berada dalam ketidakpastian. Peristiwa pandemi Covid-19 adalah peristiwa penyebaran virus yang pertama kali muncul di Wuhan, China. Penyebaran pandemi ini sangat cepat dari satu negara ke negara lain, termasuk Indonesia (Saraswati, 2020). Virus covid-19 pertama kali ditemukan di Indonesia pada bulan Maret 2020. Setelah virus ini masuk ke Indonesia, pergerakan indeks saham mengalami penurunan. Pada saat itu muncul berita mengenai penyebaran virus yang semakin meluas ke Jepang, Korea dan Singapura, sehingga penyebaran virus ini menyebabkan IHSG kita mengalami penurunan sampai dibawah level 4000 bps. Penurunan ini tentunya juga tidak lepas dari sentimen investor yang melihat bahwa pemerintah Indonesia pada waktu itu belum serius dalam menangani pandemi ini, membuat para investor lebih memilih untuk menarik dananya dari pasar modal sehingga hal tersebut tentunya membuat indeks-indeks harga saham mengalami penurunan (Fakhrunnas, 2020).

Ketidakpastian ekonomi global beberapa diantaranya dapat digambarkan oleh pergerakan indeks bursa saham global, harga minyak dunia, tingkat suku bunga The Fed di Amerika Serikat dan perubahan nilai tukar Rupiah terhadap mata uang asing (Dollar Amerika Serikat)(Nurwulandari, Hasanudin, \& Setiyo Budi, 2021). Berdasarkan data Tabel 1, maka dapat dijelaskan bagaimana pergerakan harga minyak dunia, suku bunga The Fed, nilai tukar Rupiah dan pergerakan indeks saham Dow Jones memengaruhi nilai indeks saham IDX30.

\section{Tabel 1}

Data Pergerakan Indeks Saham IDX30, Harga Minyak Dunia, Suku Bunga The Fed, Nilai Tukar Rupiah dan Indeks Dow Jones

\begin{tabular}{|c|r|r|r|r|r|}
\hline Tahun & $\begin{array}{c}\text { IDX30 } \\
\text { (Bps) }\end{array}$ & \multicolumn{1}{|c|}{$\begin{array}{c}\text { Harga Minyak } \\
\text { Dunia/Barrel }\end{array}$} & $\begin{array}{c}\text { Suku Bunga The } \\
\text { Fed (\%) }\end{array}$ & $\begin{array}{c}\text { Nilai Tukar } \\
\text { Rupiah (Rp) }\end{array}$ & $\begin{array}{c}\text { Dow Jones Industrial } \\
\text { Average Index (Bps) }\end{array}$ \\
\hline 2017 & 580,02 & 64,73 & 1,33 & 13.548 & $24.719,22$ \\
\hline 2018 & 540,77 & 45,41 & 2,40 & 14.481 & $23.327,46$ \\
\hline 2019 & 553,86 & 61,06 & 1,55 & 13.901 & $28.538,44$ \\
\hline 2020 & 502,27 & 48,52 & 0,09 & 14.105 & $30.606,48$ \\
\hline S1-2021 & 450,35 & 73,47 & 0,10 & 14.496 & $34.502,51$ \\
\hline
\end{tabular}

Sumber: IDX Website, U.S. Energy Information Administration, Economic Research (Federal Reserve Bank of St.Louis), Bank Indonesia, Investing.com, 2021 (data diolah).

Harga minyak merupakan salah satu faktor yang memengaruhi kondisi pasar modal di suatu negara, karena hampir seluruh sektor kehidupan membutuhkan energi. Harga minyak dunia diukur dengan harga spot dan yang digunakan menjadi standar adalah 
West Texas Intermediate. Minyak mentah dunia yang memiliki kualitas tinggi adalah minyak mentah yang diperdagangkan di West Texas Intermediate (WTI)(Suryanto, 2017). Harga minyak dunia bergerak fluktuatif, sehingga fluktuasi harga minyak dunia akan diikuti oleh penurunan atau kenaikan harga hasil tambang dan akan memengaruhi pendapatan perusahaan. Penurunan kinerja perusahaan akan memberikan sentimen negatif terhadap investor, sehingga nilai indeks IDX30 juga akan menurun mengikuti penurunan harga minyak dunia. Begitu pula sebaliknya apabila harga minyak mengalami kenaikan, maka nilai indeks harga saham IDX30 juga akan naik. Kondisi tersebut menunjukkan bahwa pergerakan harga minyak dunia memengaruhi nilai indeks IDX30 sebagai akibat dari fluktuasi harga minyak dunia.

Amerika Serikat memiliki pengaruh besar terhadap perekonomian Indonesia. Pengaruh kondisi ekonomi Amerika Serikat paling besar melalui jalur keuangan karena transaksi dan dana investasi yang masuk ke Indonesia kebanyakan dalam mata uang Dollar Amerika Serikat (Nurwulandari et al., 2021). Suku bunga Amerika Serikat yang biasa disebut dengan suku bunga The Fed juga merupakan faktor yang memengaruhi pergerakan indeks harga saham di Indonesia. The Fed adalah bank sentral Amerika Serikat yang memiliki tugas dan bertanggungjawab memantau dan menanggapi perkembangan perekonomian secara keseluruhan (Misgayanti \& Zuhroh, 2009). Hampir semua pasar saham internasional termasuk Bursa Efek Indonesia mengamati kondisi ekonomi di Amerika Serikat. Kebijakan yang dikeluarkan oleh bank sentral Amerika Serikat (The Fed) berhubungan dengan suku bunga acuan akan diperhatikan oleh pasar. Apabila tingkat suku bunga acuan naik maka harga saham akan turun, sebaliknya apabila tingkat suku bunga turun maka harga saham akan naik. Suku bunga The Fed pada tahun 2017 - Semester I 2021 mengalami fluktuasi. Kondisi tersebut menunjukkan bahwa perubahan nilai suku bunga The Fed memengaruhi nilai indeks IDX30, sebagai akibat dari fluktuasi nilai suku bunga The Fed.

Kinerja pasar modal Indonesia cenderung mengikuti kinerja bursa global, khususnya Indeks DJIA (Dow Jones Industrial Average). Hal ini terlihat ketika bursa global mengalami penurunan, maka indeks harga saham di Bursa Efek Indonesia juga menurun, demikian pula sebaliknya, ketika pasar saham global meningkat, maka indeks saham Indonesia juga meningkat. Investor saham di seluruh dunia menanggapi berbagai peristiwa di seluruh dunia dalam bentuk penjualan atau pembelian saham (Nurwulandari et al., 2021). Jika ada merupakan peristiwa yang dianggap dapat meningkatkan risiko investasi di masa yang akan datang, investor akan cenderung menjual saham untuk menghindari potensi kerugian di masa yang akan datang. Begitu juga jika ada peristiwa yang dianggap dapat meningkatkan potensi keuntungan, investor akan merespon dengan membeli saham di Bursa Efek Indonesia.

Selain harga minyak dunia, suku bunga The Fed dan Indeks Dow Jones, nilai tukar Rupiah terhadap mata uang Dollar Amerika Serikat (USD) juga merupakan salah satu faktor yang memengaruhi indeks harga saham di Indonesia. Nilai tukar mata uang asing dari negara maju, sangat berpengaruh terhadap kondisi ekonomi di Indonesia. Negara berkembang seperti Indonesia dengan ketergantungan impor yang tinggi, pelemahan nilai tukar sangat berdampak pada kekhawatiran akan tingginya tingkat inflasi. Harga bahan baku dari luar negeri yang tinggi mengakibatkan produsen di Indonesia menaikkan harga jual produknya, dan akhirnya berdampak pada kenaikan harga produk yang dijual (Daya, 2019). Penguatan nilai tukar Rupiah terhadap Dollar Amerika Serikat akan membuat indeks saham di Indonesia mengalami peningkatan, namun jika nilai tukar Rupiah terhadap Dollar Amerika Serikat mengalami pelemahan, maka indeks saham di Indonesia juga kenungkinan akan mengalami penurunan. Kondisi tersebut menunjukkan bahwa pergerakan nilai tukar Rupiah terhadap Dollar Amerika Serikat dengan perubahan yang sangat berfluktuasi memengaruhi pergerakan indeks saham IDX30. Seperti yang telah dijelaskan, ada banyak faktor yang memengaruhi kondisi indeks saham di Indonesia, salah satunya adalah kondisi ketidakpastian ekonomi global. Ketidakpastian ekonomi global ditunjukan diantaranya dengan pergerakan harga minyak dunia, perubahan tingkat suku bunga The Fed, pergerakan indeks saham DJIA (Dow Jones Industrial Average) dan perubahan nilai tukar Rupiah terhadap Dollar Amerika Serikat.

Berdasarkan latar belakang permasalahan tersebut, peneliti ingin menganalisis pengaruh ketidakpastian ekonomi global terhadap pergerakan indeks saham IDX30 selama pandemi Covid-19 dengan melakukan penelitian lebih lanjut dengan judul “Analisis Kondisi Ekonomi Global Terhadap Pergerakan IDX30 Selama Pandemi Covid-19”.

\section{A. Indeks Saham}

Suatu indeks yang digunakan untuk mengetahui pergerakan harga saham secara keseluruhan disebut dengan indeks saham (Wijaya, 2006). Dengan kata lain, perubahan harga saham suatu bursa di sebuah negara akan tercermin pada pergerakan nilai indeks sahamnya.

Indeks harga saham dinyatakan dalam angka indeks. Indeks harga saham adalah indikator yang dapat digunakan oleh seorang investor untuk melihat pergerakan harga saham. Dengan melihat indeks saham, maka seorang investor dapat melihat apakah pergerakan pasar pada hari ini lebih tinggi atau lebih rendah dari hari kemarin, atau dapat pula membandingkan kondisi pasar modal pada minggu lalu dibandingkan dengan kondisi pasar modal minggu ini, dan seterusnya (Sudirman, 2015).

Indeks harga saham adalah sebuah indikator yang memperlihatkan pergerakan harga saham yang terdaftar di Bursa Efek Indonesia. Indeks berfungsi sebagai indikator pergerakan pasar modal, artinya pergerakan indeks menunjukkan kondisi pasar modal pada suatu periode (Sudirman, 2015). Pergerakan indeks harga saham selalu mengikuti perkembangan rata-rata harga saham pada bursa. Jika harga sebagian besar saham emiten di bursa bersangkutan meningkat, maka nilai indeks saham juga akan mengalami peningkatan, demikian pula sebaliknya apabila harga sebagian besar saham di bursa mengalami penurunan, maka nilai indeks saham juga akan turun. 
Indeks IDX30 adalah indeks yang mengukur performa harga dari 30 saham-saham yang memiliki likuiditas tinggi dan kapitalisasi pasar besar serta didukung oleh fundamental perusahaan yang baik (IDX, 2021). Oleh karena indeks IDX30 merupakan indikator yang sangat baik sebagai indikator perubahan harga saham di bursa, maka nilai indeks IDX30 ini memerlukan cara perhitungan yang baik pula.

\section{B. Kondisi Ekonomi Global}

Ekonomi global merupakan suatu indikator ekonomi makro yang dapat memengaruhi kondisi pasar modal suatu negara. Kondisi ekonomi Indonesia seiring perkembangan Covid-19 berdampak pada berbagai sektor usaha. Pandemi Covid-19 menimbulkan penurunan produksi, penurunan daya beli masyarakat, biaya produksi yang membengkak, dan pendapatan yang sangat menurun. Nilai tukar rupiah berada pada posisi rentan selama pandemi Covid-19, yang menyebabkan kepanikan pada ekonomi global (Halisa \& Annisa, 2020). Pada saat kondisi krisis, para investor global lebih tertarik untuk menginvestasikan kekayaan yang dimiliki ke dalam aset-aset yang aman dan menghindari aset berisiko seperti saham (Haryanto, 2020). Kondisi ini mempengaruhi siklus pasar keuangan dan berdampak kepada turunnya harga saham global dan mengakibatkan penurunan IHSG termasuk indeks IDX30. Selain itu faktor eksternal ekonomi lainnya yang juga memberi dampak terhadap IDX30 adalah indeks saham global. Indeks saham global yang digunakan adalah indeks Dow Jones Industrial Average (DJIA).

Negara-negara di seluruh dunia tidak akan pernah lepas dari masalah ekonomi baik domestik maupun global yang selalu mengalami pergerakan dan dapat menimbulkan dampak dari sebuah peristiwa yang tidak terduga seperti pandemi Covid-19 saat ini. Kondisi ketidakpastian ekonomi global membuat masyarakat atau investor berhati-hati dalam berinvestasi di pasar modal. Bagi perusahaan yang go public dan melakukan perdagangan berskala internasional atau melakukan kegiatan ekspor dan impor, kondisi perekonomian global menjadi sangat berpengaruh terhadap kinerjanya sebagai emiten.

Secara langsung kondisi perekonomian global tidak memengaruhi kinerja perusahaan dalam waktu yang singkat, namun kondisi perekonomian global secara langsung dapat memengaruhi keputusan investor, karena investor selalu ingin meminimalkan risiko dan memaksimalkan keuntungan, sehingga investor akan cepat bereaksi terhadap kondisi-kondisi perekonomian global dan peristiwa-peristiwa yang tidak terduga. Ketidakpastian kondisi ekonomi global selama pandemi Covid-19 dalam penelitian ini digambarkan oleh indeks Dow Jones Industrial Average (DJIA), suku bunga The Fed, nilai tukar Rupiah terhadap Dollar Amerika Serikat dan harga minyak dunia.

\section{Indeks DJIA (Dow Jones Industrial Average)}

Indeks DJIA didirikan oleh Charles Dow, editor harian Wall Street Journal dan pendiri Dow Jones and Company (Intercontinental Exchange, 2021). Indeks ini dibuat untuk merepresentasikan kinerja saham-saham besar dan terkemuka perusahaan di Amerika Serikat kecuali untuk perusahaan transportasi dan utilitas. Indeks DJIA memuat 30 (tiga puluh) perusahaan terbesar di Amerika Serikat yang telah go public dan merupakan indeks pasar saham tertua di Amerika Serikat yang masih berjalan (Nurwulandari et al., 2021). Indeks DJIA merupakan indeks yang paling sering digunakan sebagai acuan keadaan pasar saham di AS atau New York Stock Exchange (NYSE).

\section{Suku Bunga Acuan The Fed}

The Fed (Bank Sentral Amerika Serikat) adalah badan keuangan yang bertanggung jawab dalam mengatur perbankan dan mengatur jumlah uang beredar dalam perekonomian Amerika Serikat. The Fed didirikan pada tahun 1914 setelah serangkaian kegagalan bank pada tahun 1907 (Mankiw, 2018). Suku bunga The Fed merupakan tingkat bunga yang diterapkan bank sentral Amerika Serikat untuk meminjamkan dana kepada perbankan umum yang ada di Amerika Serikat.

Kenaikan suku bunga sebagai kebijakan moneter Amerika Serikat banyak meningkatkan ketidakpastian kondisi ekonomi global. Kenaikan suku bunga The Fed tidak terlepas dari upaya bank sentral Amerika Serikat untuk memitigasi risiko kenaikan inflasi ke depan sejalan kenaikan aktivitas ekonomi Amerika Serikat yang melebihi level pertumbuhan ekonomi potensialnya.

Kenaikan suku bunga The Fed akan menurunkan harga saham, sementara penurunan suku bunga The Fed akan menaikkan harga saham. Sebab, bagi investor, naiknya tingkat suku bunga dapat menjadi berita negatif dan dinilai investasi pada pasar uang lebih menarik dibanding investasi pada pasar modal, sehingga akan terjadi perpindahan dana dari pasar modal ke pasar uang (capital outflow). Keadaan tersebut membuat penawaran lebih banyak dibanding permintaan, sehingga harga saham akan turun. Di Indonesia, ketika suku bunga The Fed naik maka surat berharga negara (SBN) ikut naik, kemudian suku bunga bank naik sehingga dinilai lebih menarik dibanding saham, akibatnya dana banyak terserap ke perbankan, sehingga memengaruhi indeks IDX30.

Berdasarkan teori diatas, dapat disimpulkan bahwa perubahan nilai suku bunga Amerika Serikat diduga dapat berpengaruh positif maupun negatif terhadap kondisi perekonomian global sehingga dapat berperan dalam pergerakan harga saham di pasar modal.

\section{E. Nilai Tukar Rupiah}

Nilai tukar Rupiah disebut juga kurs. Ada banyak alasan mengapa nilai suatu mata uang naik dan turun, namun ada dua alasan yang memengaruhi perilakunya. Pertama, suatu mata uang cenderung untuk naik dan turun secara bersamaan dengan persepsi kesehatan ekonomi dari negara yang bersangkutan. Kedua, investor mata uang cenderung untuk mengejar mata uang 
dengan nilai pengembalian yang paling tinggi.

Ketika nilai tukar Rupiah melemah (depresiasi) maka nilai indeks IDX30 akan mengalami penurunan. Hal ini disebabkan, apabila nilai tukar Rupiah terdepresiasi, maka nilai impor akan cenderung meningkat, karena meningkatnya harga barang-barang impor (memengaruhi pembelian bahan baku apabila diperoleh dari impor). Rendahnya harga barang domestik terhadap ekspor menyebabkan laba perusahaan mengalami penurunan, dampaknya harga saham perusahaan tersebut akan menurun karena investor tidak tertarik membeli saham perusahaan tersebut.

Sebaliknya, ketika nilai tukar Rupiah mengalami penguatan (apresiasi) maka nilai indeks IDX30 akan mengalami kenaikan. Hal ini disebabkan, apabila nilai tukar Rupiah terapresiasi, maka nilai impor akan cenderung menurun, karena menurunnya harga barang-barang impor (memengaruhi pembelian bahan baku apabila diperoleh dari impor). Tingginya harga barang domestik terhadap ekspor menyebabkan laba perusahaan mengalami peningkatan, dampaknya harga saham perusahaan tersebut akan naik karena investor tertarik membeli saham perusahaan tersebut.

Berdasarkan teori di atas, dapat disimpulkan bahwa perubahan nilai tukar Rupiah diduga dapat berpengaruh positif terhadap kondisi ekonomi suatu negara sehingga dapat berperan dalam pergerakan harga saham di pasar modal.

\section{F. Harga Minyak Dunia}

Minyak mentah merupakan komoditas dan sumber energi yang sangat dibutuhkan suatu negara, karena minyak mentah dapat diolah menjadi bensin, solar, Liquified Petroleum Gas (LPG), dan lain-lain. Fluktuasi harga minyak ditentukan oleh mekanisme permintaan dan penawaran (demand and supply).

Dari sisi permintaan, harga minyak dipengaruhi oleh kondisi ekonomi global. Ketika ekonomi global mengalami pertumbuhan akan diikuti dengan meningkatnya harga minyak dunia. Dari sisi penawaran, harga minyak dipengaruhi oleh ketersediaan minyak oleh negara-negara produsen, baik negara- negara yang tergabung dalam organization of the petroleum exporting countries (OPEC) maupun negara-negara non-OPEC.

Harga minyak dunia (Crude Oil Price) diukur dari harga spot pasar minyak dunia seperti West Texas Intermediate dan Brent. Minyak mentah dunia yang diperdagangkan di West Texas Intermediate (WTI) merupakan minyak dunia yang berkualitas tinggi. Hal inilah yang menyebabkan harga minyak tersebut dijadikan patokan bagi perdagangan minyak dunia.

Peran harga minyak dunia sangat penting menggerakan perekonomian suatu negara. Minyak bumi merupakan input vital dalam proses produksi industri, terutama untuk menghasilkan listrik, menjalankan mesin produksi dan mengangkut hasil produksi ke pasar (Nizar, 2002). Mengingat pentingngnya peran harga minyak, dengan fluktuasinya harga minyak memberikan dampak yang beragam terhadap suatu negara dan perusahaan.

Fluktuasi harga minyak dunia sangat memengaruhi pasar modal. Naiknya harga minyak dunia memberikan dampak yang beragam pada perusahaan. Pada perusahaan pertambangan, naiknya harga minyak dunia akan menguntungkan, apalagi jika pendapatan berbasis US Dollar. Namun pada perusahaan non- pertambangan, naiknya harga minyak dunia akan menambah biaya produksi perusahaan.

Berdasarkan teori di atas, dapat disimpulkan bahwa kenaikan harga minyak mentah dunia diduga dapat berpengaruh positif maupun negatif terhadap kondisi perekonomian global sehingga dapat berperan dalam pergerakan harga saham di pasar modal.

\section{G. Kerangka Pemikiran}

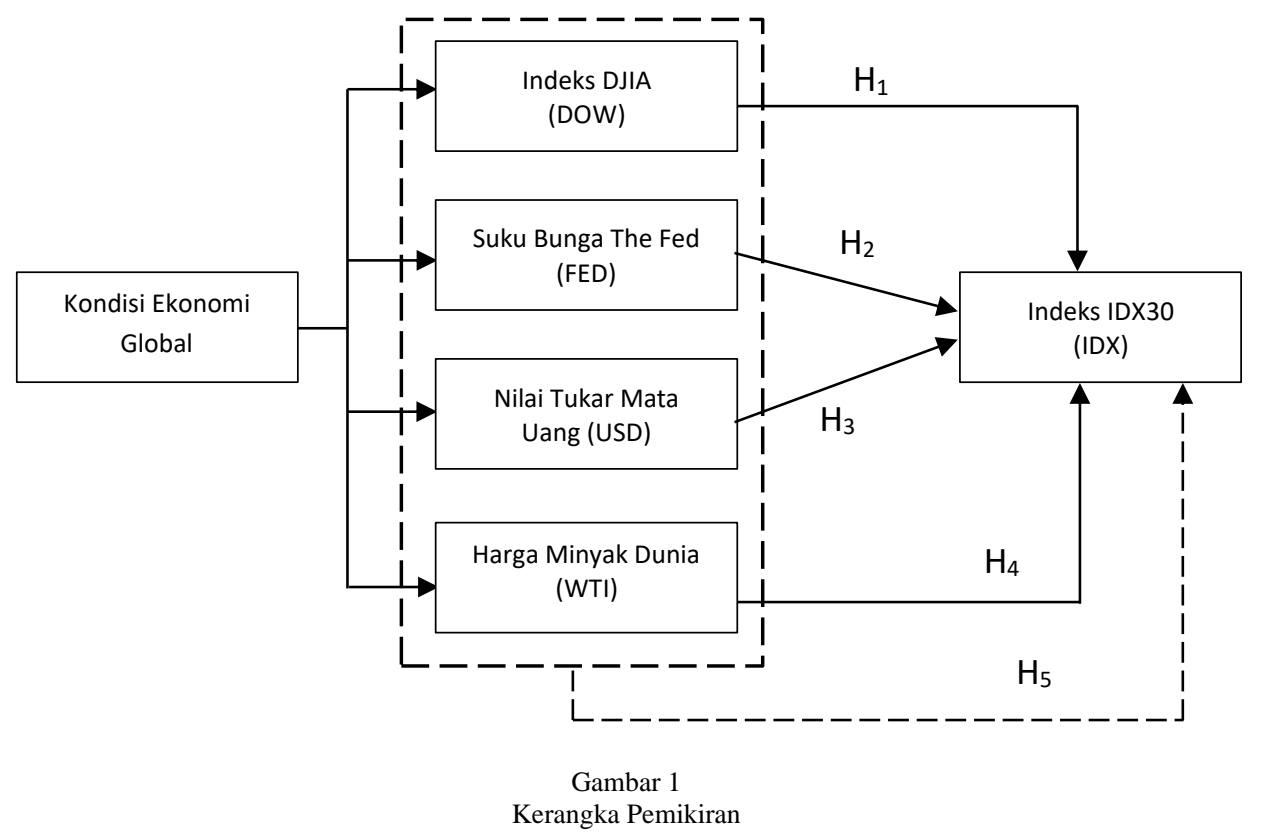

Volume 2 Nomor 2 September 2021, JAMER | 72 


\section{H. Hipotesis}

Berdasarkan tinjauan pustaka dan kerangka pemikiran yang telah dikemukakan, maka hipotesis dalam penelitian ini adalah (H1) terdapat pengaruh yang signifikan antara indeks saham DJIA (Dow Jones Industrial Average) terhadap indeks IDX30; (H2) terdapat pengaruh yang signifikan antara suku bunga The Fed terhadap indeks IDX30; (H3) terdapat pengaruh yang signifikan antara nilai tukar mata uang terhadap indeks IDX30; (H4) terdapat pengaruh yang signifikan antara harga minyak dunia terhadap indeks IDX30; (H5) terdapat pengaruh yang signifikan antara indeks Dow Jones Industrial Average, suku bunga The Fed, nilai tukar mata uang, dan harga minyak dunia terhadap indeks IDX30 secara simultan.

\section{METODE PENELITIAN}

Jenis penelitian yang digunakan dalam penelitian ini adalah penelitian asosiatif (hubungan). Dalam penelitian ini, penelitian asosiatif digunakan untuk menjelaskan tentang pengaruh indeks Dow Jones Industrial Average, suku bunga The Fed, nilai tukar mata uang, dan harga minyak dunia terhadap indeks IDX30. Populasi yang digunakan dalam penelitian ini adalah seluruh perusahaan yang masuk dalam indeks IDX30 selama periode 2019 sampai dengan Semester 1 tahun 2021. Agar dapat secara tepat menggambarkan variabel yang diteliti, maka peneliti mengambil seluruh populasi sebagai sampelnya.

Teknik pengumpulan data periode 2019 sampai dengan Semester I tahun 2021 yang dibutuhkan dalam penelitian ini diperoleh dengan mengunduh dari berbagai website atau menggunakan data sekunder. Data masing-masing variabel diperoleh dari: (a) Indeks Dow Jones Industrial Average merupakan data bulanan diperoleh dari (https://id.investing.com/indices/us-30-historicaldata) (b) Suku bunga The Fed yang merupakan data bulanan diperoleh dari (https://www.ceicdata.com/id/indicator/unitedstates/policy-rate); (c) Nilai tukar Rupiah/US\$ yang merupakan data bulanan diperoleh dari (https://www.bi.go.id/id/statistik/informasi-kurs/transaksi-bi/Default.aspx); (d) Harga minyak mentah dunia (WTI) yang merupakan data bulanan diperoleh dari (https://id.investing.com/commodities/crude-oil-historical-data); dan (e) Indeks IDX30 yang merupakan data bulanan diperoleh dari (https://idx.co.id/data-pasar/laporan-statistik/statistik/).

Metode analisis yang digunakan untuk menguji hipotesis adalah Analisis Regresi Linear Berganda. Analisis regresi ini memiliki tujuan untuk memberikan gambaran yang menyeluruh mengenai hubungan antara variabel independen dengan variabel dependen baik secara parsial maupun simultan. Beberapa tahapan dalam melakukan Analisis Regresi Linier Berganda adalah sebagai berikut:

\section{A. Uji Asumsi Klasik}

\section{HASIL DAN PEMBAHASAN}

1. Normalitas

Tabel 2

One-Sample Kolmogorov-Smirnov Test

\begin{tabular}{|c|c|}
\hline & $\begin{array}{c}\text { Unstandardized } \\
\text { Residual }\end{array}$ \\
\hline N & 105 \\
\hline Normal Parameters ${ }^{a, b}$ Mean & .0000000 \\
\hline Std. Deviation & 47.08888914 \\
\hline Most Extreme Differences Absolutes & 105 \\
\hline Positive & .105 \\
\hline & -.060 \\
\hline Test Statistic & .105 \\
\hline Asymp. Sig. (2-tailed) & $.097^{\mathrm{C}}$ \\
\hline
\end{tabular}

Sumber: Data diolah di SPSS, 2021

Dari hasil uji Kolmogorov-Smirnov diketahui bahwa nilai signifikansi atau probabilitas yaitu 0,097 atau lebih besar dari 0,05 maka dapat dinyatakan seluruh data berdistribusi normal. 
2. Multikolinieritas

Tabel 3

Hasil Uji Multikolinieritas

\begin{tabular}{|cccc|}
\hline \hline Variable & $\begin{array}{c}\text { Coefficient } \\
\text { Variance }\end{array}$ & $\begin{array}{c}\text { Uncentered } \\
\text { VIF }\end{array}$ & $\begin{array}{c}\text { Centered } \\
\text { VIF }\end{array}$ \\
\hline \hline C & 64.36314 & 31.01990 & NA \\
DOW & 0.046906 & 33.06513 & 3.081866 \\
FED & 0.041794 & 28.05461 & 2.924542 \\
USD & 0.000192 & 19.98203 & 4.272975 \\
WTI & 0.021892 & 14.60378 & 2.147949 \\
\hline \hline
\end{tabular}

Dari hasil uji multikolinieritas diatas menunjukkan bahwa seluruh variabel independen memiliki nilai Variance Inflation Factor $(\mathrm{VIF})<10$. Maka dapat disimpulkan bahwa model regresi yang digunakan dalam penelitian ini tidak terjadi multikolinieritas.

3. Analisis Regresi Linier Berganda

Teknik analisis data yang digunakan dalam penelitian ini adalah analisis regresi linear berganda untuk mengetahui pengaruh antar variabel independen dengan variabel dependen. Hasil perhitungan regresi antara variabel Indeks DJIA (DOW), suku bunga The Fed (FED), nilai tukar Rupiah terhadap Dollar Amerika Serikat (USD) dan harga minyak dunia (WTI) sebagai variabel independen terhadap indeks IDX30 sebagai variabel dependen (IDX) dapat dilihat melalui Tabel 4 sebagai berikut:

\section{Tabel 4}

\section{Hasil Analisis Regresi Linear Berganda}

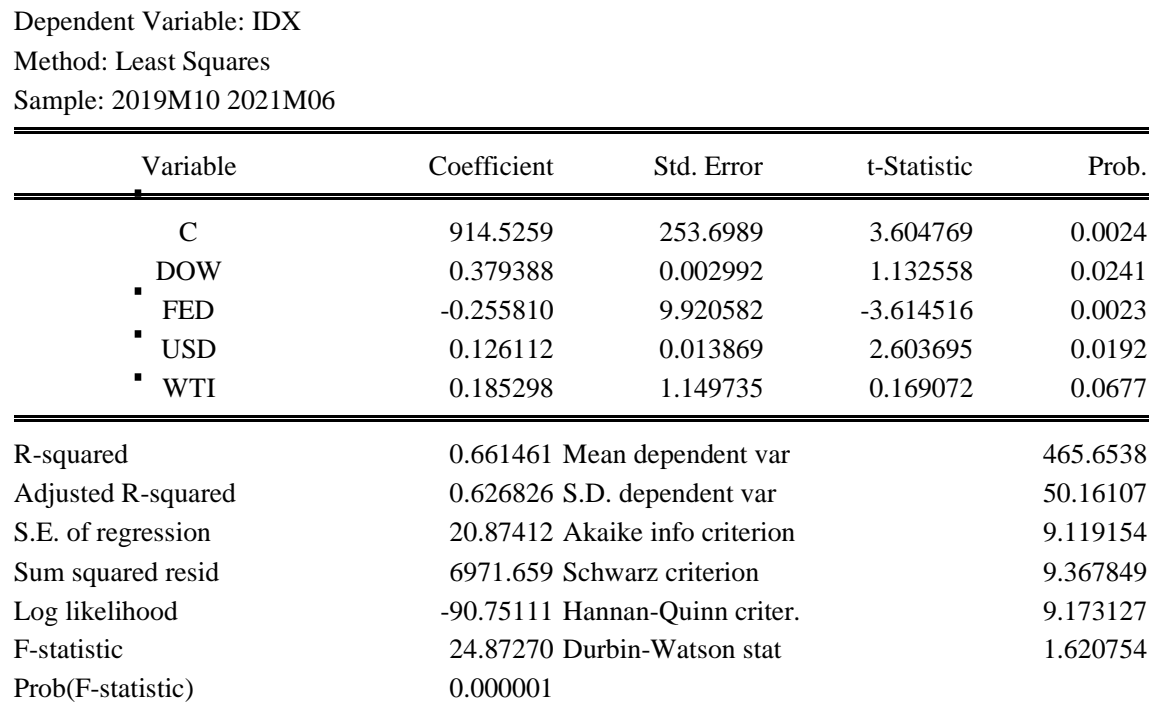

Sumber: Data diolah di Eviews, 2021

Dari persamaan regresi tersebut dapat dijelaskan sebagai berikut:

a. Koefisien variabel DOW (Indeks Dow Jones Industrial Average) sebesar 0,379388 menunjukkan bahwa jika variabel independen lain nilainya tetap dan indeks Dow Jones mengalami kenaikan 1\%, maka pergerakan IDX30 juga akan mengalami kenaikan sebesar 0,379388 bps. Koefisien bernilai positif artinya terjadi hubungan positif antara indeks Dow Jones dengan pergerakan IDX30 yaitu semakin meningkat indeks Dow Jones maka IDX30 juga akan mengalami kenaikan.

b. Koefisien variabel FED (suku bunga The Fed) sebesar -0,255810 menunjukkan bahwa jika variabel independen lain nilainya tetap dan suku bunga The Fed mengalami kenaikan 1\%, maka IDX30 akan mengalami penurunan sebesar 0,255810 bps. Koefisien bernilai negatif artinya terjadi hubungan negatif antara suku bunga The Fed dengan IDX30 yaitu semakin tingginya tingkat suku bunga The Fed maka IDX30 akan mengalami penurunan.

c. Koefisien variabel USD (kurs Rp/US\$) sebesar 0,126112 menunjukkan hubungan positif antara perubahan kurs Rp/US\$ dan pergerakan IDX30. Ketika kurs menguat sebesar 1\%, maka pergerakan IDX30 akan mengalami kenaikan sebesar 0,126112 bps, dengan asumsi variabel independen lainnya tetap. 
d. Koefisien variabel WTI (harga minyak dunia) sebesar 0,185298 menunjukkan hubungan positif antara perubahan harga minyak dunia dan pergerakan IDX30. Kenaikan perubahan harga minyak dunia sebesar $1 \%$, akan menyebabkan pergerakan IDX30 juga mengalami kenaikan sebesar 0,185298 bps, dengan asumsi variabel independen lainnya tetap.

e. Berdasarkan hasil regresi diperoleh nilai R2 sebesar 0,661461. Hal ini berarti sebesar 66,14\% variasi pergerakan IDX30 selama periode penelitian dapat dijelaskan oleh variasi keempat variabel independen (DOW, FED, USD, WTI) yang diajukan dalam penelitian ini. Sedangkan sisanya 33,86\% dijelaskan oleh variabel lain di luar model. Pada tabel di atas terlihat bahwa probabilitas F-statistik sebesar 0,000001 lebih kecil dari $\alpha$ (tingkat keyakinan 95\%, $\alpha=0,05$ ). Artinya variabel independen (DOW, FED, USD, WTI) secara bersama-sama berpengaruh terhadap pergerakan IDX30.

f. Berdasarkan hasil analisis regresi linear berganda, terlihat bahwa variabel DOW adalah variabel yang memiliki koefisiensi beta yang paling besar yaitu 0,379388. Artinya, variabel IDX lebih banyak dipengaruhi oleh variabel indeks Dow Jones Industrial Average (DOW) dibanding variabel lain.

\section{B. Pembahasan}

1. Pengaruh Indeks Dow Jones Average Industrial (DOW) Terhadap Pergerakan Indeks IDX30 (IDX) Berdasarkan hasil analisis terlihat bahwa indeks Dow Jones memiliki hubungan yang positif dan signifikan terhadap pergerakan IDX30 dengan nilai koefisien sebesar 0,379388. Hal ini berarti setiap peningkatan indeks Dow Jones sebesar 1 bps akan diikuti oleh peningkatan IHSG sebesar 0,379388 bps. Hasil signifikan yang diperoleh menunjukkan bahwa pengaruh indeks Dow Jones terhadap IDX30 terdapat integrasi antara pasar modal di Amerika Serikat (bursa efek global) dengan pasar modal di Indonesia dalam kurun waktu penelitian. Hal ini bisa terjadi disebabkan oleh beberapa faktor, seperti kondisi ekonomi Indonesia dan ekonomi Amerika Serikat selama pandemi Covid-19 yang mengalami kelesuan dan usaha masingmasing negara untuk mengeluarkan kebijakan-kebijakan sebagai upaya pemulihan ekonomi.

2. Pengaruh Suku Bunga The Fed (FED) Terhadap Pergerakan Indeks IDX30 (IDX)

Berdasarkan hasil penelitian, menunjukkan bahwa variabel suku bunga The Fed memiliki pengaruh negatif dan signifikan terhadap indeks IDX30, sehingga hipotesis dalam penelitian ini diterima, yang artinya terdapat pengaruh yang signifikan antara suku bunga The Fed terhadap pergerakan indeks IDX30 di Bursa Efek Indonesia. Arah negatif dalam penelitian ini menunjukkan bahwa ketika tingkat suku bunga The Fed mengalami kenaikan, maka pergerakan indeks IDX30 akan mengalami penurunan, sementara itu ketika tingkat suku bunga The Fed mengalami penurunan maka pergerakan indeks IDX30 akan mengalami kenaikan, sehingga hasil penelitian ini sesuai dengan teori yang menyatakan bahwa apabila tingkat suku bunga acuan naik, maka pergerakan indeks saham akan turun.

3. Pengaruh Nilai tukar Rp/USD (USD) Terhadap Pergerakan Indeks IDX30 (IDX)

Berdasarkan hasil penelitian yang diperoleh bahwa variabel nilai tukar Rp/USD memiliki pengaruh signifikan terhadap pergerakan indeks IDX30 dan arah hubungannya positif, sehingga hipotesis dalam penelitian ini diterima, yang artinya terdapat pengaruh yang signifikan antara nilai tukar Rp/USD terhadap pergerakan indeks IDX30 di Bursa Efek Indonesia. Kuat lemahnya nilai tukar Rupiah akan berdampak pada perusahaan, termasuk perusahaan go public yang terdaftar di Bursa Efek Indonesia (BEI). Pada periode penelitian yaitu tahun 2019-S1 2021, pergerakan nilai tukar Rupiah terhadap Dollar Amerika Serikat cenderung berfluktuasi terutama pada awal tahun 2020, dimana pada bulan Maret 2020 pertama kalinya kasus Covid-19 ditemukan di Indonesia sehingga sangat mempengaruhi kondisi ekonomi. Akibatnya pergerakan indeks IDX30 juga mengalami penurunan. Melemahnya nilai tukar Rupiah terhadap Dollar Amerika Serikat menjadi salah satu penyebab menurunnya harga saham di Bursa Efek Indonesia, karena melemahnya nilai tukar Rupiah terhadap Dollar Amerika Serikat akan membuat harga komoditi impor menjadi tinggi.

Sebaliknya, menguatnya nilai tukar Rupiah terhadap Dollar Amerika Serikat menjadi salah satu alasan meningkatnya harga saham di Bursa Efek Indonesia, karena nilai tukar yang menguat akan membuat harga barang impor menjadi turun, sehingga terjadi kenaikan laba perusahaan. Kenaikan laba perusahaan membuat investor tertarik untuk membeli saham perusahaan tersebut dan akan menciptakan permintaan yang lebih banyak dibanding penawaran sehingga berdampak terhadap kenaikan harga saham. Apabila harga saham meningkat, maka akan menyebabkan pula pergerakan indeks IDX30 mengalami peningkatan, sebagai dampak dari kenaikan harga rata-rata saham yang diperdagangkan di Bursa Efek Indonesia.

4. Pengaruh Harga Minyak Dunia (WTI) Terhadap Pergerakan Indeks IDX30 (IDX)

Berdasarkan hasil penelitian, menunjukkan bahwa harga minyak dunia memiliki pengaruh positif tetapi tidak signifikan terhadap indeks IDX30, sehingga hipotesis dalam penelitian ini diterima, yang artinya terdapat pengaruh antara harga minyak dunia terhadap indeks IDX30 di Bursa Efek Indonesia. Tidak signifikannya pengaruh harga minyak dunia disebabkan kenaikan atau penurunan (fluktuasi) harga minyak dunia memberikan dampak yang berbeda terhadap perusahaan yang menjadi anggota indeks IDX30. Pada perusahaan yang bergerak di sektor pertambangan, kenaikan harga minyak dunia menguntungkan karena perusahaan tersebut akan mendapatkan penghasilan yang lebih besar sehingga laba perusahaan meningkat. Hal tersebut membuat investor tertarik untuk membeli sahamnya dan terjadi peningkatan permintaan lebih besar daripada penawaran, sehingga menjadikan harga saham perusahaan tersebut meningkat. 
Namun bagi perusahaan yang bergerak di sektor non pertambangan, kenaikan harga minyak dunia akan berdampak pada meningkatnya beban produksi perusahaan, dan berimbas pada menurunnya laba perusahaan. Laba perusahaan yang menurun membuat masyarakat atau investor tidak tertarik untuk membeli saham perusahaan tersebut dan terjadi peningkatan penawaran lebih besar daripada permintaan, sehingga harga sahamnya akan menurun.

5. Pengaruh Indeks Dow Jones Industrial Average, Suku Bunga The Fed, Nilai tukar Rp/USD, dan Harga Minyak Dunia Terhadap Indeks IDX30 Secara Simultan

Berdasarkan hasil penelitian secara simultan menunjukkan bahwa variabel Indeks Dow Jones Industrial Average, suku bunga The Fed, nilai tukar Rp/USD, dan harga minyak dunia memiliki pengaruh yang signifikan terhadap indeks IDX30. Hasil penelitian ini menunjukkan bahwa Indeks Dow Jones Industrial Average, suku bunga The Fed, nilai tukar Rp/USD, dan harga minyak dunia pada periode penelitian sebagai salah satu faktor penentu yang dapat menjelaskan keragaman atas pergerakan indeks IDX30 di Bursa Efek Indonesia. Hal ini berarti investor melihat informasi Indeks Dow Jones Industrial Average, suku bunga The Fed, nilai tukar Rp/USD, dan harga minyak dunia sebelum membeli saham untuk memperkirakan harga saham di masa yang akan datang.

6. Variabel Bebas yang Berpengaruh Dominan Terhadap Pergerakan Indeks IDX30

Berdasarkan hasil penelitian, variabel Indeks Dow Jones Industrial Average memiliki pengaruh dominan terhadap pergerakan indeks IDX30 dengan nilai koefisien beta sebesar 0,379388.

\section{KESIMPULAN}

\section{A. Kesimpulan}

Berdasarkan hasil penelitian yang telah diuraikan, maka kesimpulan dari penelitian ini adalah:

1. Indeks Dow Jones memiliki pengaruh yang positif dan signifikan terhadap pergerakan IDX30. Hasil signifikan yang diperoleh menunjukkan bahwa pengaruh indeks Dow Jones terhadap IDX30 terdapat integrasi antara pasar modal di Amerika Serikat (bursa efek global) dengan pasar modal di Indonesia dalam kurun waktu penelitian. Hal ini bisa terjadi disebabkan oleh beberapa faktor, seperti kondisi ekonomi Indonesia dan ekonomi Amerika Serikat selama pandemi Covid-19 yang mengalami kelesuan dan usaha masing-masing negara untuk mengeluarkan kebijakan-kebijakan sebagai upaya pemulihan ekonomi.

2. Suku bunga The Fed berpengaruh negatif dan signifikan terhadap pergerakan indeks IDX30. Hal ini berarti apabila terjadi kenaikan pada suku bunga The Fed maka akan menyebabkan penurunan pada nilai indeks IDX30 di Bursa Efek Indonesia.

3. Nilai tukar Rp/USD berpengaruh positif dan signifikan terhadap pergerakan indeks IDX30. Hal ini berarti apabila nilai tukar Rupiah melemah (depresiasi) terhadap Dollar Amerika Serikat, maka akan menyebabkan penurunan pada nilai indeks IDX30 di Bursa Efek Indonesia. Adanya pengaruh positif, menguatnya nilai tukar Rupiah terhadap Dollar Amerika Serikat akan membuat harga komoditi ekspor menjadi tinggi, sehingga akan meningkatkan pendapatan perusahaan. Peningkatan laba perusahaan membuat investor tertarik membeli saham perusahaan tersebut, akibatnya harga saham dan indeks IDX30 akan naik.

4. Harga minyak dunia tidak berpengaruh signifikan terhadap indeks IDX30 di Bursa Efek Indonesia. Tidak signifikannya pengaruh disebabkan perusahaan dalam anggota indeks IDX30 terdiri dari perusahaan pertambangan dan non pertambangan, sehingga naiknya harga minyak dunia hanya berpengaruh terhadap perusahaan pertambangan dalam indeks IDX30. Sedangkan, naiknya harga minyak dunia tidak berpengaruh terhadap perusahaan non pertambangan.

5. variabel Indeks Dow Jones Industrial Average, suku bunga The Fed, nilai tukar Rp/USD, dan harga minyak dunia secara simultan berpengaruh signifikan terhadap indeks IDX30 di Bursa Efek Indonesia.

6. Indeks Dow Jones Industrial Average memiliki pengaruh dominan terhadap pergerakan indeks IDX30 di Bursa Efek Indonesia. Hal ini disebabkan, Indeks Dow Jones Industrial Average merupakan salah satu indeks saham yang menjadi referensi bagi para investor dalam mengambil keputusan untuk melakukan investasi atau transaksi saham di Bursa Efek Indonesia.

\section{B. Saran}

Berdasarkan pembahasan dan kesimpulan, selanjutnya dapat diusulkan saran yang diharapkan akan bermanfaat bagi investor, emiten, pemerintah, serta penelitian selanjutnya berkaitan dengan faktor-faktor yang memengaruhi harga saham di indeks IDX30 adalah investor sebaiknya memerhatikan kondisi ekonomi global terutama yang berkaitan dengan pergerakan Indeks Dow Jones Industrial Average sebelum berinvestasi di pasar modal, hal ini didasarkan pada hasil penelitian yang menunjukkan bahwa variabel tersebut memiliki pengaruh dominan terhadap pergerakan indeks IDX30. Selain itu, bagi para emiten yang perusahaannya masuk dalam kategori indeks IDX30 perlu memerhatikan tingkat suku bunga The Fed dan nilai tukar Rupiah terhadap Dollar Amerika Serikat agar bisa memberikan kebijakan dan respon yang tepat untuk keberlangsungan usahanya. Untuk pemerintah perlu memerhatikan tingkat suku bunga The Fed dan nilai tukar Rupiah terhadap mata uang asing agar dapat membuat keputusan yang tepat terkait kebijakan makro, karena suku bunga The Fed dan nilai kurs mampu mengendalikan pergerakan indeks IDX30. 


\section{DAFTAR PUSTAKA}

Daya, S. (2019). Analisis Pengaruh Tingkat Suku Bunga, Inflasi, dan Pendapatan Nasional Terhadap Nilai Tukar Rupiah di Indonesia Periode Tahun 2001-2018. Skripsi. Universitas HKBP Nommensen. Retrieved from http://repository.uhn.ac.id/handle/123456789/4076

Exchange, I. (2021). Dow Jones Industrial Average. Retrieved from https://www.nyse.com/quote/index/DJI

Fakhrunnas, F. (2020). Investasi Sebelum dan Sesudah Pandemi Covid-19, Bagaimana Pengaruhnya? Retrieved from https://fecon.uii.ac.id/blog/2020/08/01/investasi-sebelum-dan-sesudah-pandemi-covid-19-bagaimana-pengaruhnya/

Halisa, N. N., \& Annisa, S. (2020). Pengaruh Covid-19, Nilai Tukar Rupiah dan Indeks Harga Saham Gabungan terhadap Pergerakan Indeks Harga Saham Gabungan (IHSG). Jurnal Manajemen Dan Organisasi, 11(3), 170-178. https://doi.org/10.29244/jmo.v11i3.32657

Haryanto. (2020). Dampak Covid-19 terhadap Pergerakan Nilai Tukar Rupiah dan Indeks Harga Saham Gabungan (IHSG). The Indonesian Journal of Development Planning, 4(2), 151-165.

Indonesia, B. E. (2021). IDX. Retrieved September 9, 2021, from https://idx.co.id/produk/indeks/

Mankiw, N. G. (2018). Pengantar Ekonomi Makro Edisi Ke-7. Jakarta: Salemba Empat.

Misgayanti, ., \& Zuhroh, I. (2009). Pengaruh Suku Bunga Luar Negeri Federal Reserve (the Fed), Nilai Tukar Rupiah/Us \$ Dan Inflasi Terhadap Indeks Harga Saham Gabungan Di Bursa Efek Indonesia Periode 2006-2008. Jurnal Ekonomi Pembangunan, 7(1), 19. https://doi.org/10.22219/jep.v7i1.3580

Nizar, M. A. (2002). Kenaikan Harga Minyak Dunia Dan Implikasinya Bagi Indonesia [Increasing The World'S Oil Price And Implications For Indonesia]. IDEAS. Retrieved from https://ideas.repec.org/p/pra/mprapa/65770.html

Nurwulandari, A., Hasanudin, H., \& Setiyo Budi, A. J. (2021). Analysis of the Influence of Interest Rate, Exchange Value, World Gold Prices, Dow Jones Index, AEX Index, DAX Index, and Shanghai Index on LQ45 Index in Indonesia Stock Exchange 2012 - 2018. JABE (Journal of Applied Business and Economic), 7(2), 135. https://doi.org/10.30998/jabe.v7i2.7824

Saraswati, H. (2020). Dampak Pandemi Covid-19 Terhadap Pasar Saham Di Indonesia. Jurnal Riset Akuntansi \& Keuangan Dewantara, 3(2), 153-163. Retrieved from http://ejournal.stiedewantara.ac.id/index.php/JAD/issue/view/54

Sudirman. (2015). Pasar Modal dan Manajemen Portofolio. Gorontalo: Sultan Amai Press.

Suryanto, S. (2017). Pengaruh Harga Minyak Dan Emas Terhadap Indeks Harga Saham Gabungan Di Bursa Efek Indonesia. JURISMA : Jurnal Riset Bisnis \& Manajemen, 7(1), 1-13. https://doi.org/10.34010/jurisma.v7i1.439

Wijaya, J. A. (2006). Bursa Berjangka. Yogyaka: Andi. 